\title{
DANO ESTÉTICO
}

\author{
Alexandre Augusto de Castro Corrêa \\ Professor Catedrático da Faculdade de Direito da \\ Universidade de São Paulo
}

As deformações faciais e as mutilações, para lembrarmos os casos mais expressivos, são fonte de infelicidade, tristezas, ansiedades, angústias e mesmo de neuroses, sentimentos esses que embora de índole psicológica são abrangidos pela reparação civil duma espécie de dano moral, a saber, o dano estético. Desse tema ocupa-se a professora Teresa Ancona Lopez de Magalhães no livro O Dano Estético Responsabilidade Civil (1 v., 123 p., publicado em 1980 pela editora RT). As discussões sobre a reparabilidade do dano estético são, mutatis mutandis, análogas às travadas a respeito da avaliação do dano moral em dinheiro. E delas, depois de breve capítulo sobre este último, trata a autora na seguinte ordem: conceito de dano estético; situações diversas podendo originar o dano estético; avaliação do dano estético; sua indenização; o dano estético em outras legislações; análise concreta das hipóteses de reparação do dano estético no Direito brasileiro.

Depois de citar as definições de Wilson Melo da Silva, Mário Pogliani e René Chapus, a autora propõe sua conceituação pessoal: dano estético é "qualquer modificação duradoura ou permanente na aparência externa da pessoa, modificação essa acarretando-lhe 'enfeamento' que por sua vez causa humilhação $e$ desgostos, originando portanto uma dor moral" (p. 18).

A autora faz em seguida a conveniente distinção entre os critérios do Direito Civil que se contenta com a simples modificação "para pior" e o do Direito Penal exigindo deformações graves para incriminar seus causadores. Prossegue mostrando como o dano estético deve impor à vítima prejuízo permanente ou pelo menos prolongado. E cita a propósito (p. 88) julgado de tribunal francês concedendo indenização em favor de certa grande dama parisiense que durante dois meses e meio viu-se impedida de usar vestido decotado, em consequiência de tratamento danoso de sua epiderme... A professora analisa depois a abundante casuística sobre permanência da lesão, restaurações insatisfatórias ou, pelo contrário, restaurações para melhor, acarretando ou excluindo indenização por dano estético.

A autora termina este capítulo exigindo como é lógico que o dano estético origine dano moral, causando à vítima sentimentos de humilhação, tristeza, 
desgosto, etc., e conclui: "Há, então, um sofrimento moral tendo como causa uma ofensa à integridade física e este é o ponto principal do conceito de dano estético". Esse dano é por outro lado relativo, dependendo da idade, do sexo, da posição social do ofendido, etc. Representa finalmente lesão a um direito de personalidade (pp. 24 e ss.).

Quanto às diversas situações podendo originar dano estético, depois de distinguir entre dano delitual e contratual, entre obrigação de meio e de resultado, a autora examina situações concretas suscetíveis de originar danos estéticos: acidentes, atos criminosos, atos dos agentes do poder público, acidentes de trabalho, dano estético em consequiência do transporte de passageiros, dano estético resultante de cirurgia plástica ou causado por enfermeiros, dentistas, cabeleireiros, etc., terminando por discutir a autolesão.

Capítulos centrais da tese são evidentemente o quinto, sobre o problema da avaliação e indenização do dano estético, e os dois últimos sobre a reparação desse dano em nosso Direito e no Direito estrangeiro.

Quanto ao primeiro, a reparação pecuniária do pretium doloris em casos de dano estético parece esbarrar com a censura formulada nos idos de 1948 por Ripert, o qual a propósito de reparação do dano moral em dinheiro considerava chocante ir mercadejar, por assim dizer, as próprias lágrimas perante os tribunais ( $L e$ prix de la douleur). Demogue, citado por Sílvio Rodrigues in Responsabilidade Civil pergunta: "será preciso ir a ponto de conceder indenização ao marido traído por sua mulher?". Esmein é autor de La commercialisation du dommage moral (1954), obra citada por Weill e Terré na $2^{\mathrm{a}}$ ed. de Les obligations (Dalloz, $2^{\mathrm{a}}$ ed., 1975, p. 668 , n. 3). Os mesmos autores em nota 2, p. 670 da mesma obra lembram os diversos danos sofridos por mulher, cujo marido se tornou impotente em conseqüência de grave acidente. O marido, aliás, poderia também pleitear indenização por dano estético no caso de ter sofrido mutilação...

Os romanos, em texto de Gaio citado pela autora (D. 9, 3, 7: "não se levarão, porém, em conta as cicatrizes nem as deformações causadas pelo acidente pois a estimativa em dinheiro do prejuízo sofrido pelo corpo dum homem livre é inadmissivel" - tradução nossa), rejeitavam nossa indenização por dano estético tanto pelo apreço, para nós excessivo, por eles tributado à dignidade do homem livre quanto talvez, por serem povo guerreiro, pelo orgulho das cicatrizes deixadas nos embates corpo a corpo. Também nas universidades alemãs, até fins do século 
passado, as cicatrizes no rosto em conseqüência de duelos eram sinal distintivo dos estudantes aristocráticos.

$\mathrm{O}$ argumento, porém, grato ao pensamento contemporâneo nessa matéria é o exposto por Von Thur em citação de Sílvio Rodrigues, Responsabilidade Civil (Saraiva, 1995, p. 190, n. 77): "esta prestação (por dano moral e estético) proporciona à vítima um aumento de seu patrimônio e que ela pode destinar a quaisquer espécies de prazeres, materiais ou ideais. A satisfação daí resultante e o fato de saber que a soma de dinheiro foi tomada ao culpado devem amenizar a amargura da ofensa e saciar dalguma forma o desejo de vingança ainda nãodesaparecido no homem moderno, apesar do cristianismo e da civilização". Maior realismo não se poderia desejar nesta matéria.

Para a professora Teresa, a questão da reparabilidade do dano moral em dinheiro está hoje resolvida pela afirmativa, pois "muito mais imoral seria deixar o dano irresarcido" (p. 68).

Resta, pois, encontrar critérios para determinar o quantum debeatur, nos casos de dano estético. E aqui entramos no aspecto casuístico da questão do pretium doloris, encarado em compensação em vez de ressarcimento ou indenização. Leva-se, ainda, em conta o sexo, a idade, a condição social do ofendido, sua profissão e a gravidade ou extensão da beleza perdida; tais elementos componentes do dano estético são apreciados segundo o prudente arbítrio do julgador.

Seria extenso demais, nos limites duma resenha, analisar todos os aspectos da monografia da autora que escreve com muita inteligência, mantendo sempre vivo o interesse dos leitores.

São Paulo, fevereiro de 1996. 